\title{
KAJIAN MACAM PUPUK HAYATI TERHADAP INTENSITAS PENYAKIT BERCAK DAUN Cercospora Sp PADA TANAMAN JAGUNG HITAM
}

\author{
Nining saputri*, Sartono Joko Santosa, Saiful Bahri \\ Fakultas Pertanian, Universitas Slamet Riyadi, Surakarta \\ *E-mail: niningsaputri60@gmail.com
}

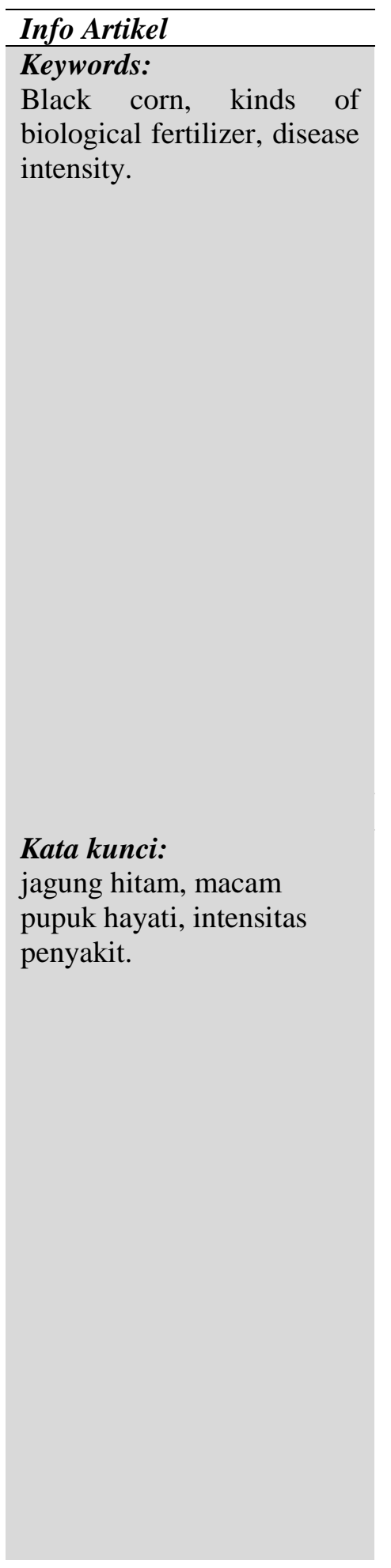

\begin{abstract}
This study is titled Study of Biological Fertilizers on the intensity of Leaf Spots (Cercospora sp.) On Black Corn (Black Aztec) with the aim to study the types of biological fertilizers on the intensity of Cercospora sp. which began on November 9, 2019, in Jembangan Village, Gagaksipat Village, Ngemplak District, Boyolali District, Central Java, with a height of $150 \mathrm{~m}$ (asl). This study uses a single factor Complete Randomized Block Design (RCBD) consisting of 10 treatments and 3 replications. The data from the results of this study were analyzed with the Duncan at the 5\% level. The parameters observed include: intensity of leaf spot disease, weight of cob with corn husk per plant (gram), weight of cob without corn husk per plant (gram), weight of 100 corn seeds (gram). The results showed that: (1) Symptoms of leaf spot disease appear evenly on all biological fertilizers, symptoms of disease attack began to appear at the age of 30 days after planting. (2) In the treatment of biological fertilizer Megharizo on black corn concertration $10 \mathrm{ml} / 1,21$ (B2) can reduce the intensity of leaf spot disease. (3) The application of biological fertilizer from three doses has not been able to increase the yield of black corn to the weight of corn with corn husk, weight of corn without corn husk, and weight of 100 seeds.
\end{abstract}

\footnotetext{
Abstrak

Penelitian ini berjudul Kajian Macam Pupuk Hayati Terhadap Intensitas Penyakit Bercak Daun (Cercospora sp.) Pada Jagung Hitam (Black Aztec) dengan tujuan untuk mengkaji macam pupuk hayati terhadap intensitas penyakit bercak daun Cercospora sp. yang dilaksanakan mulai tanggal 9 November 2019, di Dusun Jembangan, Desa Gagaksipat, Kecamatan Ngemplak, Kabupaten Boyolali, Jawa Tengah, dengan ketinggian tempat 150m (dpl). Penelitian ini menggunakan metode Rancangan Acak Kelompok Lengkap (RAKL) faktor tunggal yang terdiri dari 10 perlakuan dan 3 kali ulangan. Data hasil penelitian ini dianalisis dengan uji Duncan pada taraf 5\%. Parameter-parameter yang diamati meliputi: Intensitas penyakit bercak daun, berat tongkol dengan kulit jagung per tanaman (gram), berat tongkol tanpa kulit jagung per tanaman (gram), berat 100 biji jagung (gram). Hasil penelitian menunjukkan bahwa: (1) Gejala serangan penyakit bercak daun tampak merata pada pupuk hayati semua, gejala serangan penyakit mulai muncul pada umur 30 hari setelah tanam. (2) Perlakuan pupuk hayati Megharizo pada jagung hitam dengan konsentrasi 10 $\mathrm{ml} / 1,21$ (B2) dapat menekan intensitas penyakit bercak daun. (3) Pemberian pupuk hayati dari tiga dosis belum mampu meningkatkan hasil jagung hitam terhadap berat jagung dengan
}

Nining Saputri, Sartono Joko santosa, Saiful Bahri 
ISSN (Print) : 1693-0738

ISSN (Online) : 2714-5549

Innofarm:Jurnal Inovasi Pertanian Vol. 22 (1), April 2020

kulit jagung, berat jagung tanpa kulit jagung, dan berat 100 biji.

\section{PENDAHULUAN}

Jagung merupakan salah satu tumbuhan penghasil karbohidrat sebagai makanan pokok manusia yang paling penting selain padi dan gandum. Menyebut jagung, secara langsung orang akan membayangkan bulir-bulir kuning yang menempel pada tongkol kokoh yang keras, dari pohon yang mirip tebu dan ilalang besar. Tetapi ada juga jagung yang berwarna hitam atau yang bernama lain Black Aztec, dimana warna hitam ini adalah warna alami dari jagung, jagung hitam adalah jenis jagung yang istimewa karena adanya pigmen yang membuat bijinya berwarna hitam pekat. Warnanya yang hitam bukanlah hasil rekayasa genetik, melainkan disebabkan adanya kandungan antosianin sejenis flavonoid. Selain dikonsumsi biasa, jagung hitam juga bisa dikeringkan dan diolah menjadi tepung hitam untuk membuat roti. Jagung hitam juga kaya akan nutrisi yang baik bagi kesehatan, beberapa nutrisi tersebut diantaranya yaitu asam filkat, asam amino, potasium, kalsium, selenium, niasin, zat besi, serat dan lemak (Yulianti, 2018).

Pupuk hayati mampu meningkatkan efisiensi serapan hara, memperbaiki pertumbuhan dan hasil serta diyakini meningkatkan ketahanan terhadap serangan hama dan penyakit. Pupuk hayati merupakan suatu bahan yang mengandung mikro organisme bermanfaat untuk meningkatkan kuantitas dan kualitas hasil tanaman. Melalui aktivitas biologi akhirnya dapat berinteraksi dengan sifat fisik dan kimia tanah (Simalongo, 2008).

Penyakit bercak daun adalah salah satu jenis penyakit yang umumnya menyerang beberapa jenis tanaman budidaya. Penyakit ini cukup meresahkan petani. Bukan hanya karena merugikan secara ekonomi, tetapi juga sangat mudah menyebar. Seperti umumnya jenis penyakit yang disebabkan oleh jamur, penyakit bercak daun juga sangat mudah menular ke tanaman sehat lainnya. Oleh sebab itu, jika tidak dikendalikan secara tepat, maka penyakit ini akan sangat merugikan. Biasanya penyakit ini mulai muncul saat musim hujan dan kondisi kelembaban cukup tinggi (Anonim. 2014).

Gejala penyakit bercak daun Cercopsora ditandai dengan adanya bercak-bercak berwarna kepucatan yang awalnya berukuran kecil, akhirnya secara perlahan membesar. Pada bagian pinggiran daun terdapat bercak berwarna lebih tua dari warna bercak dibagian tengahnya. Selain itu sering terjadi sobekan di pusat bercak tersebut. Jika sudah seperti ini daun akan berubah warna menjadi kekuning-kuningan sebelum akhirnya gugur (Setiadi, 2011).

Tujuan penelitian ini untuk mengetahui intensitas serangan penyakit bercak daun cercospora sp terhadap macam pupuk hayati. Diduga dengan pemberian macam pupuk hayati Megarhizo dengan 10 $\mathrm{ml} / 1,21$ dapat menekan intensitas serangan penyakit bercak daun cercospora sp pada tanaman jagung hitam

\section{BAHAN DAN METODE}

Dalam penelitian ini menggunakan Rancangan Acak Kelompok Lengkap ( RAKL ) yang terdiri dari 10 perlakuan dengan 3 kali ulangan. Analisis selanjutnya menggunakan Uji Duncan pada taraf 5\% untuk mengetahui pengaruh masing - masing perlakuan terhadap intensitas hama dan hasil tanaman jagung hitam. Bahan yang digunakan antara lain : benih jagung hitam. Pupuk hayati yang digunakan yaitu pupuk Biotogrow, pupuk Megarizho, dan pupuk M-BIO sesuai dengan rekomendasi. Alat yang digunakan yaitu : Meteran, Timbangan, label, cangkul, gembor, benang, ember, alat tulis. Penelitian telah dilaksanakan pada tanggal 9 November sampai tanggal 22 January, yang dilaksanakan di dusun Jembangan Desa Gagaksipat kecamatan Ngemplak kabupaten Boyolali dengan ketinggian tempat 150 mdpl dan jenis tanahnya grumosol.

Pengamatan dilakukan sejak tanaman berumur 30 hari setelah tanam dengan pengamatan setiap dua minggu sekali. Pada pengolahan lahan ini membuat petakan sebanyak 30 petak dengan tiap petaknya berukuran $200 \mathrm{~cm}$ x $100 \mathrm{~cm}$. Sedangkan jarak tanam dalam petak yaitu 70 x $20 \mathrm{~cm}$ yang nantinya didalam petak tersebut terdapat 18 tanaman jagung, dengan mengambil 4 sempel daun yang diserang setiap 1 tanaman yang diamati. Dengan parameter antara lain : gejala serangan penyakit, intensitas kerusakan, berat jagung dengan kulit, berat jagung tanpa kulit, berat 100 biji pertanaman. 
ISSN (Print) : 1693-0738

ISSN (Online) : 2714-5549

Innofarm:Jurnal Inovasi Pertanian Vol. 22 (1), April 2020

\section{HASIL DAN PEMBAHASAN \\ Gejala serangan}

Hasil pengamatan yang telah dilakukan selama 60 hari dengan intensitas pengamatan 2 minggu sekali di lahan, penyakit bercak daun cercospora sp menyerang tanaman jagung pada umur jagung 30 hari setelah tanam. gejala awal sangat jelas pada daun ketiga dan keempat dari pucuk yaitu mula-mula timbul bercak-bercak berwarna kepucatan yang awalnya berukuran kecil akhirnya secara perlahan melebar. Pada bagian pinggir daun terdapat bercak berwarna lebih tua dari warna bercak di bagian tengah lama kelamaan daun akan berubah warna menjadi kekuning-kuningan sebelum akhirnya gugur. Kerapatan tanaman juga dapat mempengaruhi produksi tanaman. Hal ini terkait dengan tingkat kompetisi antar tanaman dalam memperoleh unsur hara, air, cahaya matahari (Diyan, 2015.

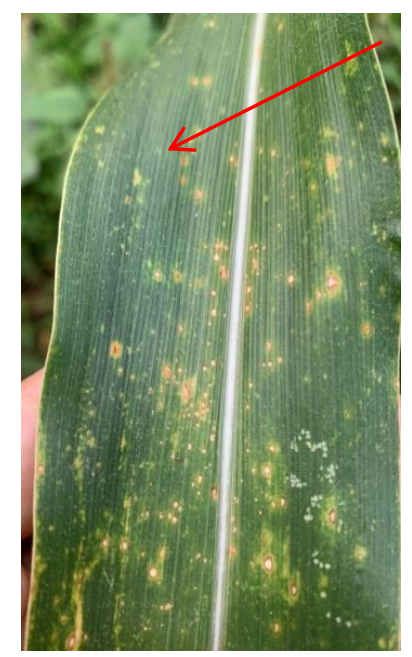

Gejala serangan penyakit bercak daun

Intensitas Penyakit Bercak daun

Tabel 1. Intensitas kerusakan penyakit dari pengamatan pertama sampai ke terakhir.

\begin{tabular}{cccc}
\hline Perlakuan & Rengamatan 1 & Rata-rata intensitas penyakit & Pengamatan 2 \\
\hline Kontrol & $11,06 \mathrm{a}$ & $12,36 \mathrm{a}$ & $13,40 \mathrm{a}$ \\
A1 & $10,48 \mathrm{a}$ & $11,48 \mathrm{ab}$ & $12,22 \mathrm{ab}$ \\
A2 & $10,48 \mathrm{a}$ & $11,25 \mathrm{ab}$ & $12,21 \mathrm{ab}$ \\
A3 & $9,79 \mathrm{a}$ & $11,69 \mathrm{ab}$ & $12,64 \mathrm{ab}$ \\
B1 & $9,66 \mathrm{a}$ & $10,73 \mathrm{ab}$ & $11,62 \mathrm{ab}$ \\
B2 & $8,20 \mathrm{~b}$ & $10,03 \mathrm{~b}$ & $10,84 \mathrm{~b}$ \\
B3 & $9,79 \mathrm{a}$ & $10,73 \mathrm{ab}$ & $11,62 \mathrm{ab}$ \\
C1 & $9,10 \mathrm{a}$ & $10,50 \mathrm{ab}$ & $12,35 \mathrm{ab}$ \\
C2 & $9,79 \mathrm{a}$ & $10,89 \mathrm{ab}$ & $11,65 \mathrm{ab}$ \\
C3 & $10,93 \mathrm{a}$ & $11,02 \mathrm{ab}$ & $11,87 \mathrm{ab}$ \\
\hline
\end{tabular}

Keterangan : Purata intensitas kerusakan hama yang diikuti huruf yang sama berarti tidak berbeda nyata pada taraf $5 \%$ uji Duncan. 
Tabel 1 intensitas serangan penyakit pengamatan pertama sampai terakhir menunjukkan pupuk hayati Megharizo B2 berbeda nyata dengan kontrol. Pada pupuk hayati M-BIO dan pupuk hayati BiotoGROW tidak berbeda nyata pada perlakuan kontrol. Penyebaran penyakit yang disebabkan oleh jamur sangat terbantu kelembaban yang tinggi, oleh sebab itu kerapatan populasi perlu diperhatikan dalam rangka mengendalikan penyakit bercak daun. Bercak daun Cercospora sp muncul pertama umur 21 hari dan meningkat pada umur 28 hari, meningkatnya bercak daun Cercospora sp karena faktor lingkungan yang mendukung pertumbuhan jamur (Santoso, 2001),

\section{HASIL TANAMAN}

Tabel 2. Hasil Panen

\begin{tabular}{cccc}
\hline Perlakuan & Berat tongkol dengan kulit & Berat tongkol tanpa kulit & Berat 100 Biji \\
\hline Kontrol & $88.47 \mathrm{ab}$ & $63.40 \mathrm{a}$ & $36.50 \mathrm{a}$ \\
$\mathrm{A} 1$ & $100.27 \mathrm{ab}$ & $75.60 \mathrm{a}$ & $34.27 \mathrm{a}$ \\
$\mathrm{A} 2$ & $103.83 \mathrm{ab}$ & $73.03 \mathrm{a}$ & $36.23 \mathrm{a}$ \\
$\mathrm{A} 3$ & $84.77 \mathrm{ab}$ & $71.10 \mathrm{a}$ & $36.57 \mathrm{a}$ \\
$\mathrm{B} 1$ & $98.70 \mathrm{ab}$ & $61.83 \mathrm{a}$ & $35.77 \mathrm{a}$ \\
$\mathrm{B} 2$ & $82.47 \mathrm{ab}$ & $75.60 \mathrm{a}$ & $29.23 \mathrm{a}$ \\
$\mathrm{B} 3$ & $103.83 \mathrm{ab}$ & $78.90 \mathrm{a}$ & $36.83 \mathrm{a}$ \\
C1 & $94.87 \mathrm{ab}$ & $54.73 \mathrm{a}$ & $36.83 \mathrm{a}$ \\
C2 & $115.77 \mathrm{a}$ & $81.83 \mathrm{a}$ & $34.23 \mathrm{a}$ \\
C3 & $81.30 \mathrm{~b}$ & $66.37 \mathrm{a}$ & $35.47 \mathrm{a}$ \\
\hline
\end{tabular}

Keterangan : Purata hasil panen yang diikuti huruf sama berarti tidak nyata pada taraf $5 \%$ uji Duncan (Duncan Multiple Range Test / DMRT)

Tabel 2. Berdasarkan tabel 2 menunjukkan bahwa berat jagung dengan kulit jagung, berat jagung tanpa kulit jagung dan berat 100 biji tidak berbeda nyata dengan control. Dapat dilihat bahwa berat jagung dengan kulit jagung pada pupuk BiotoGROW C2 menghasilkan rata-rata tertinggi 115,77 gram dan rata-rata terendah terdapat pada C3 dengan rata-rata 81,30 gram. Pada pupuk Megarhizo rata-rata tertinggi yaitu pada B3 dengan rata-rata 103,83 gram. Sedangkan rata-rata terendah yaitu pada B2 dengan rata-rata 82,47 gram. Pada pupuk M-BIO rata-rata tertinggi yaitu pada A2 dengan rata-rata 103,83 gram sedangkan rata-rata terendah pada $A 3$ dengan rata-rata 84,77 gram.

Hakim et.al. (1986) menyatakan, bahwa ketersediaan unsur hara yang dapat diserap oleh tanaman merupakan salah satu faktor yang dapat mempengaruhi tingkat produksi suatu tanaman. Apabila didalam tanah cukup tersedia unsur-unsur hara yang siap diserap oleh akar tanaman dalam keadaan cukup seimbang maka akan daat meningkatkan pertumbuhan dan hasil suatu tanaman (Sarief, 1989).

Dapat dilihat bahwa berat jagung tanpa kulit jagung pada pupuk hayati BiotoGROW C2 menghasilkan rata-rata 81,83 gram dan rata-rata terendah pada $\mathrm{C} 1$ dengan rata-rata 54,73 gram. Pada pupuk hayati Megarhizo rata-rata tertinggi yaitu pada B3 dengan rata-rata 78,90 gram. Sedangkan rata-rata terendah yaitu pada B1 dengan rata-rata 61,83 gram. Pada pupuk hayati M-BIO rata-rata tertinggi yaitu pada A1 dengan rata-rata 75,60 gram. Sedangkan rata-rata terendah yaitu pada A3 dengan rata-rata 70,10 gram.

Adnan, 2006 menyatakan, faktor - faktor yang mempengaruhi tebal suatu bahan hasil pertanian adalah jenis tanaman, varietas, tempat tumbuh, iklim, kesuburan tanah dan kadar air bahan tersebut. Kadar air merupakan salah satu faktor yang mempengaruhi tebal suatu bahan hasil pertanian. Jika kandungan air dalam suatu bahan tinggi, maka akan menyebabkan ukuran sel mengembang dan secara langsung akan mempengaruhi tebalnya.

Dapat dilihat bahwa berat 100 biji pada pupuk hayati BiotoGROW C2 menghasilkan rata-rata tertinggi yaitu 36,83 gram dan rata-rata terendah terdapat pada $\mathrm{C} 1$ dengan rata-rata 29,23 gram. Pada pupuk Megarhizo rata-rata tertinggi yaitu pada B2 dengan rata-rata 36,57 gram. Sedangkan rata-rata 
ISSN (Print) : 1693-0738

ISSN (Online) : 2714-5549

Innofarm:Jurnal Inovasi Pertanian Vol. 22 (1), April 2020

terendah yaitu pada B1 dengan rata-rata 32,53 gram. Pada pupuk M-BIO rata-rata tertinggi yaitu pada A1 dengan rata-rata 36,50 gram. Sedangkan rata-rata terendah yaitu pada A2 dengan rata-rata 34,27 gram.

Menurut Takdir et al. (1998), hasil biji jagung dipengaruhi oleh interaksi antara genotip dengan lingkungan. Kemampuan produksi tanaman jagung merupakan resultan dari beberapa faktor komponen produksi seperti jumlah baris biji dan berat biji yang dihasilkan yang digambarkan pada hasil akhir berupa produksi biji pipilan kering.

Peran pupuk hayati dalam penelitian ini dianggap masih belum memberikan pengaruh terhadap hasil pipilan jagung. Walaupun potensi mikroba yang ada dalam pupuk hayati cukup besar. Azotobacter mampu menghasilkan substansi pemacu tumbuh seperti auksin dan giberelin dan. Selain Azotobacter, Azospirillum juga menghasilkan IAA yang memacu pertumbuhan akar dan rambut akar sehingga daerah serapan hara diperluas. Azospirillum juga menghasilkan vitamin berupa tiamin, niasin dan pantotenik yang bersinergi dengan auksin dalam memacu pertumbuhan dan produksi tanaman (Surtiningsih \& Mariam. 2011; Setiawati. 2014).

\section{KESIMPULAN}

Berdasarkan hasil dan pembahasan maka dapat disimpulkan sebagai berikut :

1. Gejala serangan penyakit bercak daun tampak merata pada semua perlakuan pupuk hayati, gejala serangan penyakit muncul pada umur 30 hari setelah tanam.

2. Perlakuan pupuk hayati Megharizo pada jagung hitam dengan konsentrasi $10 \mathrm{ml} / 1,21$ (B2) dapat menekan intensitas penyakit bercak daun.

3. Pemberian pupuk hayati dari tiga dosis belum mampu meningkatkan hasil jagung hitam terhadap berat jagung dengan kulit jagung, berat jagung tanpa kulit jagung, dan berat 100 biji.

\section{DAFTAR PUSTAKA}

Adnan. A.A. 2006. Karakterisasi Fisika Kimia dan Mekanis Kelobot Jagung Sebagai Bahan Kemasan. Bogor. Fakultas Teknologi Pertanian. Institut Pertanian Bogor. 87 Hal

Anonim, 2014. Cara Mengatasi Penyakit Bercak Daun Pada Tanaman Budidaya. (https://gdmorganic.com/bercak-daun, diakses tanggal 27 oktober 2019).

Hakim, N., et.al. 1986. Dasar-Dasar Ilmu Tanah. Lampung : Universitas Lampung

Diyan P.M, Y. Sartono Joko Santosa, Kharis Triyono. 2015. Kajian Dosis Pupuk Hayati Terhadap Intensitas Penyakit Bercak Daun (Cercospora sp) Pada Tanaman Jagung Semi ( Zea Mays L).

Jurnal Inovasi Pertanian vol. 14, No.1.

Santoso JS. 2001. Ilmu Penyakit Tanaman. Surakarta : FAPERTA UNISRI. 86 hal.

Sarief, S. 1986. Kesuburan dan Pemupukan Tanah Pertanian. Bandung : Pustaka Buana

Setiadi, 2011. Bertanam Cabai Di Lahan dan Pot. Jakarta : Penebar Swadaya.

Setiawati, M. R. 2014. Peningkatan Kandungan N dan P Tanah serta Hasil Padi Sawah Akibat Aplikasi Azolla Pinnata dan Pupuk Hayati Azotobacter Chroococcum dan Pseudomonas cepaceae. Agrologia, 3 (1): 61-74

Simalongo E, 2008. Pupuk Hayati Ramah Lingkungan, Menghemat Pupuk Kimia Hingga 50\%. http://iklanhouse.com/pupuk-revolusier-tiens-golden-harvest/. (Diakses 21 September 2014). 
Surtiningsih, T \& S. Mariam. 2011. Efektivitas Campuran Pupuk Hayati dengan Pupuk Kimia pada Pertumbuhan dan Produksi Tanaman Selada Bokor (Lactuca sativa L.) var Crispa. J. Matematika dan Ilmu Pengetahuan Alam 14 (2): 4-8

Takdir A., R. N. Iriany, M. Dachlan, F. Kasim dan A. Barata. 1998. Stabilitas hasil beberapa genotipe hibrida jagung harapan. Risalah Penelitian Jagung dan Serealia Lain. 1 (4) : 7-14.

Yulianti, Dyan. 2018. “inilah fakta mengenai jagung hitam” (online). (https://www-kompasianacom.cdn.ampproject.org/v/s/www.kompasiana. com/amp/dyanyulianti/5be959e386e7e5f7c/eksotis-bukan-gosong-inilah-fakta-mengenaijagung-hitam, diakses tanggal 16 september 2019). 